\title{
Game Simulasi Manajemen Produksi Game Dengan Metode Agile Development
}

\section{Game Production Management Simulation Game Using Agile Development Method}

\author{
Irfan Dwi Rahadianto \\ Desain Komunikasi Visual, Fakultas Industri Kreatif, Universitas Telkom, \\ Bandung, Jawa Barat, Indonesia \\ dwirahadianto@telkomuniversity.ac.id
}

Naskah diterima tanggal 01/05/2021, direvisi akhir tanggal 12/07/2021, disetujui tanggal 12/08/2021

\begin{abstract}
Abstrak
Industri game berkembang sangat pesat pada akhir 2010 hingga 2019. Di Indonesia sendiri, pada tahun 2017 industri game Indonesia memiliki nilai pasar sebesar $\$ 879$ milyar dan diprediksikan akan terus berkembang setiap tahunnya. Namun dari fenomena yang terjadi pada industri game didalam maupun diluar negeri menunjukan indikasi kurangnya pengetahuan dan pemahaman tentang metode pengelolaan pengembangan game yang mengakibatkan gagal produksi, sehingga dapat menghambat perkembangan dan penyerapan ekonomi kreatif, khususnya pada sektor industri game di Indonesia. Penelitian ini bertujuan untuk memberikan pengalaman dan edukasi tentang metode manajemen produksi game kepada pengembang game pemula melalui game simulasi, agar gagal produksi dapat dihindari. Metode penelitian ini menggunakan metode kualitatif dan pendekatan edukasi first principles of instruction oleh Merrill (2002) dengan kerangka berfikir design thinking. Dalam penelitian ini ditemukan bahwa pengembang game pemula kurang memiliki pengalaman dalam mengelola pengembangan game sehingga memiliki resiko kegagalan yang tinggi dalam fase produksi. Hasil penelitian ini menunjukan bahwa game simulasi yang menerapkan metode edukasi Merrill dapat secara efektif memberikan pengalaman dan edukasi pada pengembang game pemula mengenai metode manajemen produksi game, dimana pengembang pemula dapat mengetahui proses-proses yang harus dilakukan pada fase produksi game.
\end{abstract}

Kata Kunci: Manajemen Produksi, Produksi Game, Game Simulasi, Edukasi.

\begin{abstract}
1434 / 5000 Translation results The game industry grew very rapidly from the end of 2010 to 2019. In Indonesia alone, in 2017 the Indonesian game industry had a market value of $\$ 879$ billion and is predicted to continue to grow every year. However, the phenomena that occur in the game industry at home and abroad show indications of a lack of knowledge and understanding of game development management methods that result in production failure, so that it can hinder the development and absorption of the creative economy, especially in the game industry sector in Indonesia. This study aims to provide experience and education about game production management methods to novice game developers through simulation games, so that production failures can be avoided. This research method uses qualitative methods and the educational approach of first principles of instruction by Merrill (2002) with a design thinking framework. In this study it was found that novice game developers lack experience in managing game development so they have a high risk of failure in the production phase. The results of this study indicate that simulation games that apply Merrill's educational method can effectively provide experience and education to novice game developers regarding game production management methods, where novice developers can find out the processes that must be carried out in the game production phase.
\end{abstract}

Keywords: Production Management, Game Production, Simulation Game, Education.

How to cite (APA Style) : Rahadianto, I D. (2021). Game simulasi manajemen produksi game dengan metode agile development.

Jurnal Penelitian Pendidikan, 21 (2), 2021. 49-65. doi: https://doi.org/10.17509/jpp.v21i2.37405 


\section{PENDAHULUAN}

Di Indonesia, industri kreatif berkembang pesat pada akhir tahun 2010 hingga 2019. Menurut Bekraf, terdapat lima belas sektor industri kreatif, salah satunya adalah Pengembang Aplikasi dan Game. Di tahun 2016, nilai pasar industri game Indonesia mencapai \$321 Miliar dan akan terus meningkat setiap tahunnya. Hal ini terbukti pada tahun berikutnya, dimana nilai pasarnya meningkat menjadi $\$ 879$ Miliar. Nilai pasar tersebut bahkan lebih besar dari seluruh sektor industri kreatif di Indonesia jika nilai pasarnya digabungkan. Ini merupakan peluang yang baik bagi banyak pengembang dan pengusaha game lokal untuk mulai berbisnis di industri game di Indonesia. Namun, pengembang game lokal hanya mencapai $0,4-1 \%$ dari total nilai pasar, dan sayangnya nilai tersebut berkurang setiap tahunnya (Arief, 2017).

Terdapat banyak tantangan didalam pasar game Indonesia, mulai pengembang game asing yang memiliki sumber daya dan produk game yang lebih menarik bagi pemain lokal, hingga metode manajemen produksi game yang kurang dipahami oleh pengembang game lokal khususnya pengembang pemula. Pada proyek game Kickstarter yang paling di tunggu-tunggu di Indonesia, garapan Tinker Games yang berjudul Pale Blue harus berhenti produksinya, menurut pernyataan Tinker Games pada situs kampanye Kickstarter-nya menyatakan bahwa, mereka tidak memiliki peran yang dapat mengelola scope, timeline, dan keuangan berdasarkan sumber daya yang ada di dalam proyek game Pale Blue, sehingga mengalami kegagalan. Hal ini dikonfirmasi oleh project director dari Tinker Games, dimana tidak ada timeline, proses manajemen produksi, alokasi sumber daya manusia dan budgeting yang jelas dalam produksi game Pale Blue, dan yang paling fatal adalah scope project game Pale Blue yang terlalu besar untuk karyawan yang dimiliki (Dicky, 2019).

Fenomena ini juga tidak hanya terjadi pada pengembang game lokal, salah satu proyek game yang diantisipasi dunia, Project Phoenix garapan studio yang berbasis di Jepang, CIA, Inc., mengalami hambatan dalam proses produksinya. Hambatan tersebut disebabkan oleh kelalaian tim pengembang utama dalam mengelola alokasi tugas sumber daya manusia yang dimiliki untuk membantu merampungkan game yang akan dikerjakan (Hiroaki, 2019).

Metode manajemen produksi game merupakan aspek yang penting, namun berdasarkan fenomena yang terjadi, masih banyak pengembang game pemula yang belum memahami dan mengimplementasikan metode manajemen produksi game. Selain itu, manajemen produksi game merupakan aspek yang kompleks, maka dibutuhkan suatu media yang dapat menyampaikan metode manajemen produksi game dengan sederhana dan menyenangkan, agar lebih mudah dipahami. Dengan mensimulasikan aspek manajemen produksi game kedalam game simulasi, metode manajemen produksi game dapat disampaikan dengan lebih sederhana, menyenangkan dan mudah dipahami.

\section{METODE PENELITIAN}

Metode penelitian ini menggunakan metode kualitatif deskriptif dengan kerangka berfikir design thinking. Design Thinking merupakan kerangka berfikir untuk memecahkan permasalahan yang spesifik yang berfokus pada manusia (human-centered design) sebagai pengguna (Hasso Plattner, 2010; Christian Müller-Roterberg, 2020). Konsep design thinking terdiri dari lima elemen yaitu empathize, define, ideate, prototyping, dan test, dimana lima elemen tersebut dapat membantu penulis dalam memberi gambaran yang spesifik dalam permasalahan pengembang game pemula untuk dipetakan permasalahannya dan mengambil langkah-langkah yang tepat, sebagai landasan dalam merancang game simulasi metode manajemen produksi game. 
Berikut adalah pemaparan kerangka pemikiran design thinking untuk penelitian ini tersaji dalam Gambar 1.

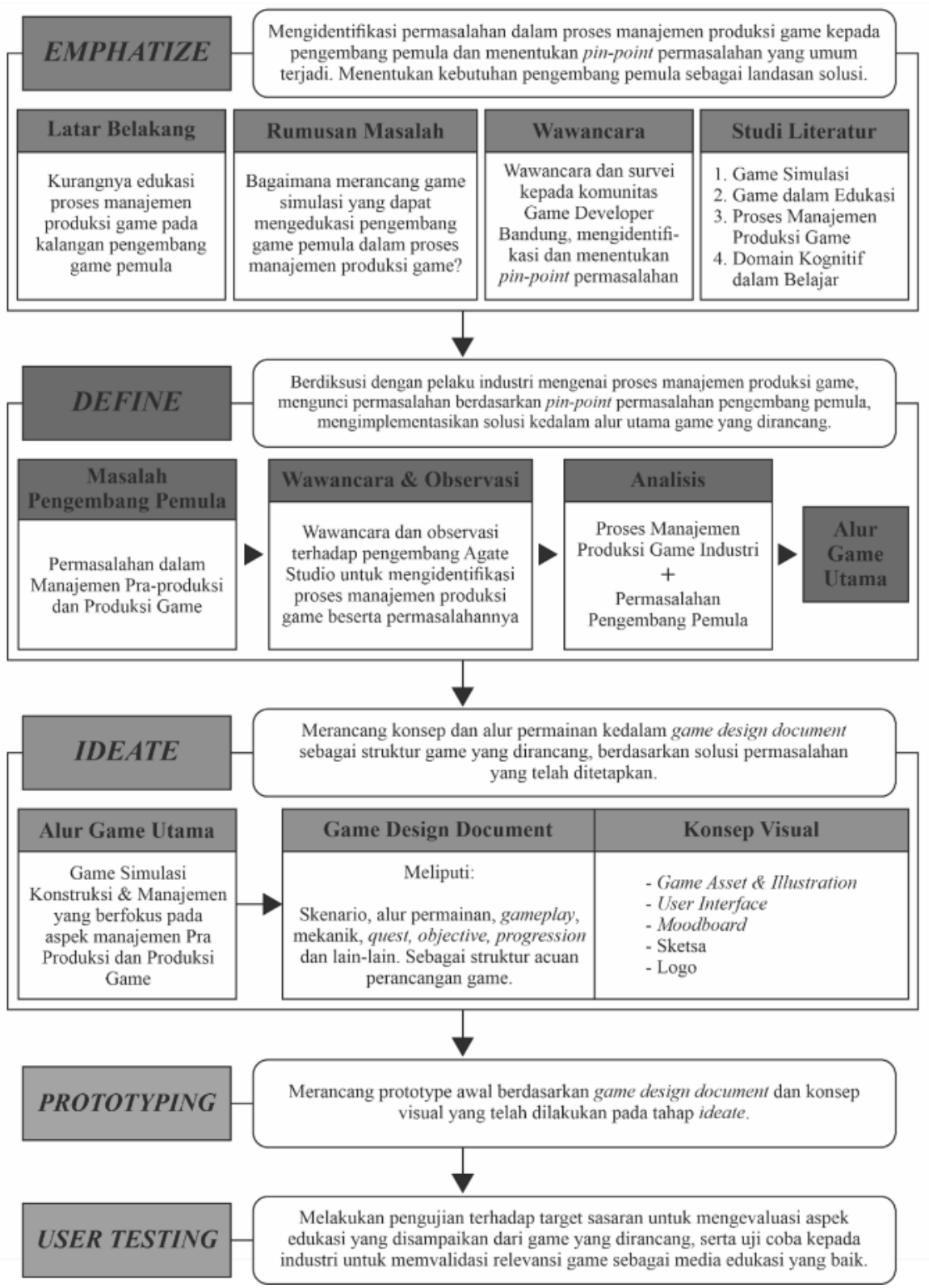

Gambar 1. Diagram Alur Perancangan

\section{Emphatize}

Mengidentifikasi permasalahan dalam manajemen produksi game pada pengembang pemula dan menentukan permasalahan yang umum terjadi. Kemudian menentukan kebutuhan pengembang game pemula sebagai landasan solusi.

\section{Define}

Berdiskusi dengan pelaku industri mengenai metode manajemen produksi game yang efektif dan mengunci permasalahan berdasarkan kebutuhan pengembang game pemula. 


\section{Ideate}

Merancang konsep dan alur permainan kedalam game design document sebagai struktur game yang dirancang, berdasarkan solusi permasalahan yang telah ditetapkan.

\section{Prototyping}

Merancang purwarupa awal berdasarkan game design document dan konsep visual yang telah dilakukan pada tahap ideate.

\section{User Testing}

Melakukan pengujian terhadap target sasaran untuk mengevaluasi aspek edukasi yang disampaikan dari game yang dirancang.

\section{First principles of instruction}

Selain itu penelitian ini menggunakan pendekatan first principles of instruction oleh Merrill (2002). First principles of instruction merupakan instrumen instruksi kepada pemain dalam berinteraksi dari pemain terhadap games. Keterkaitan elemen di dalam game dengan first principles of instruction dapat memfasilitasi pembelajaran dengan hasil yang substansial. First principles of instruction memiliki lima prinsip yang membentuk seperangkat elemen fundamental yang umum untuk edukasi yang efektif, diantaranya Problem, Activation, Demonstration, Application dan Integration (Merrill, 2002; Miller, 2009).

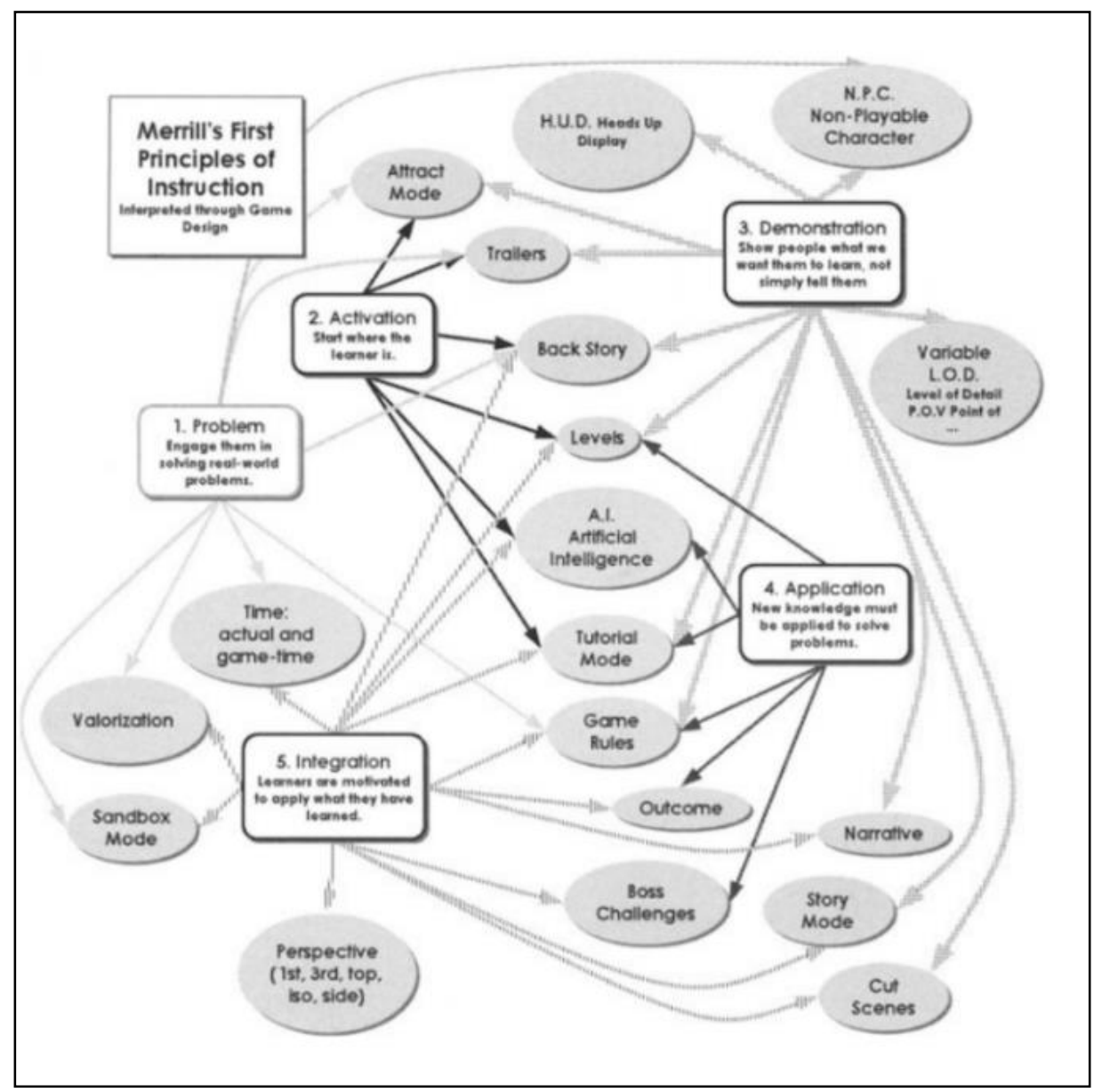

Gambar 2. Keterkaitan Elemen Game dengan First Principle of Instruction. Sumber: Merrill, 2002 dalam Miller, 2009 


\section{HASIL DAN PEMBAHASAN \\ Hasil \\ Emphatize}

Dalam tahap ini penulis melakukan wawancara dan survei terhadap pengembang game pemula dan komunitas Game Developer Bandung untuk mengetahui permasalahan utama yang dialami. Wawancara dilakukan dengan ketua Game Developer Bandung, Barli Achmad Jabbar dan CEO studio game indie Visionesia Studio, Dicky Jiang.

Dari wawancara kepada Dicky Jiang dan Barli Achmad Jabar, penulis dapat mengidentifikasi permasalahan yang umum dialami pengembang game pemula, yaitu kurangnya pengetahuan, pengalaman dan pemahaman terhadap metode pengelolaan produksi game, meliputi perencanaan (planning), perekrutan karyawan (staffing), tugas-tugas yang harus dikerjakan oleh masing-masing disiplin (to do / task list / process execution), batasan waktu pengerjaan (timeline) dan perkiraan terhadap besar kecilnya suatu proyek game dengan sumber daya yang ada (scope project). Untuk mendapatkan data yang holistik, penulis juga melakukan survei terhadap komunitas Game Developer Bandung. Total responden adalah 50 orang.

Hasil survei yang dilakukan pada komunitas Game Developer Bandung menunjukan bahwa 53\% pengalaman mengembangkan game kurang dari 1 tahun dan dapat dikategorikan sebagai pengembang pemula dapat dilihat pada gambar 3 .



Gambar 3. Pengalaman dalam Developing Games.

Sedangkan aspek penting dalam mengembangkan game 64.3\% menunjukan Pra-Produksi dapat dilihat pada gambar 4 .



Gambar 4. Aspek Penting dalam Developing Games. 
Lalu pada aspek penting dalam Pra-Produksi responden 63.2\% memilih Konsep Game sebagai aspek yang paling penting dapat dilihat pada gambar 5.

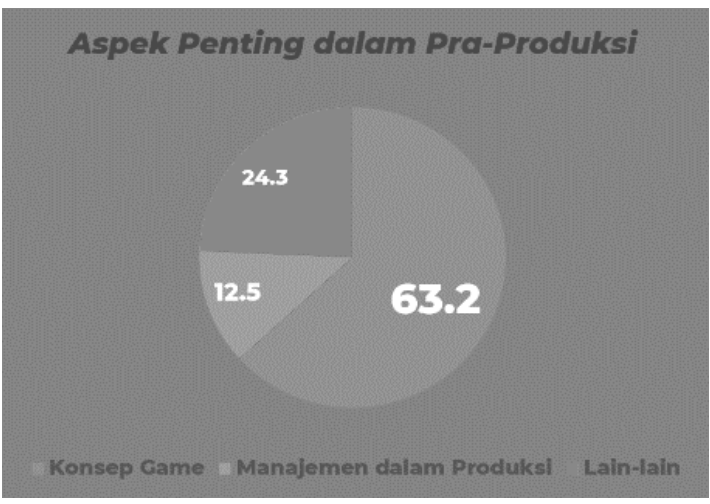

Gambar 5. Aspek Penting dalam Pra-Produksi.

Hasil survei yang dilakukan pada komunitas Game Developer Bandung menunjukan bahwa 53\% pengalaman mengembangkan game kurang dari 1 tahun dan dapat dikategorikan sebagai pengembang pemula (Gambar 3). Sedangkan aspek penting dalam mengembangkan game $64.3 \%$ menunjukan PraProduksi (Gambar 4). Lalu pada aspek penting dalam Pra-Produksi responden $63.2 \%$ memilih Konsep Game sebagai aspek yang paling penting (Gambar 5). Hasil ini menunjukan bahwa manajemen dalam produksi game masih belum dianggap penting oleh pengembang game pemula, dimana selaras dengan hipotesis awal berdasarkan fenomena yang terjadi.

\section{Define}

Tahap selanjutnya penulis melakukan studi lapangan berupa wawancara kepada Surya selaku Game Producer di Agate International mengenai pandangan tentang permasalahan umum yang terjadi pada pengembang game pemula, serta metode manajemen produksi game yang digunakan oleh pengembang game berpengalaman di industri. Selain itu penulis juga melakukan observasi terhadap proses dan lingkungan kerja di Agate International. Adapun Proses Pra-Produksi game di Agate Studio dapat dilihat pada gambar 6.

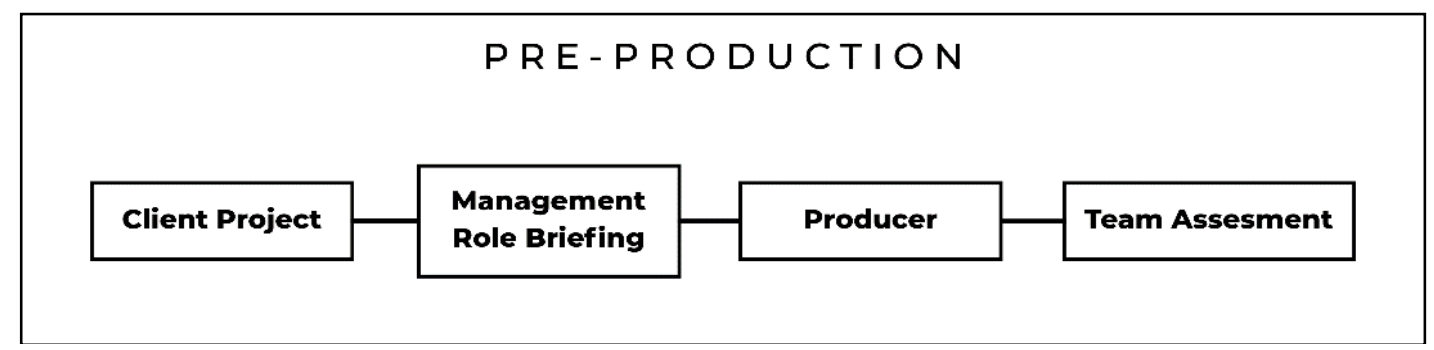

Gambar 6. Proses Pra-Produksi Game di Agate Studio.

Agate International menggunakan metode Agile Development sebagai metode utama dalam mengembangkan game. Proses pengembangan biasanya dibagi menjadi tiga bagian, pra-produksi, produksi, dan paska produksi, namun pada bagian GM (Gamification), biasanya pra-produksi telah rampung oleh pihak klien dan management Agate, atau biasa disebut dengan Brief Quest, sehingga langsung masuk ke tahap produksi. Namun kondisi tersebut sangat situasional, jika ada Brief Quest yang memiliki banyak fitur atau belum ada sama sekali Brief Quest, maka akan dilakukan tahap praproduksi sekitar satu hingga dua minggu. Setelah semua aspek sudah jelas dari klien dan pihak 
management, maka ditentukan tim yang akan memproduksi, mulai dari artist, programmer, dan designer.

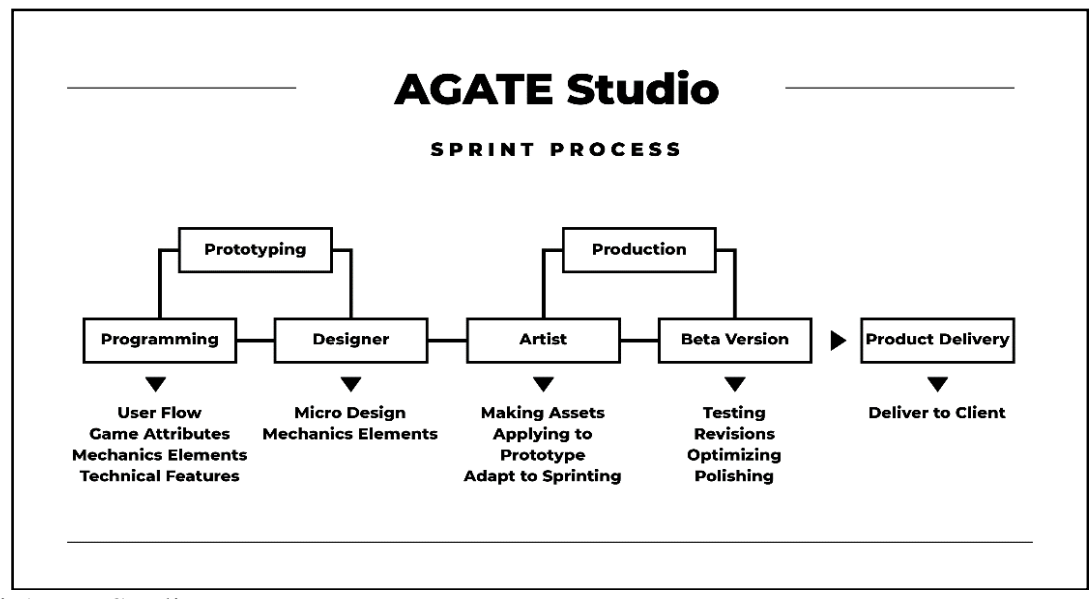

Gambar 7. Proses Sprint di Agate Studio.

Dalam tahap produksi target utama yang dikejar adalah flow game dan user journey-nya berdasarkan dari brief yang klien dan management sepakati untuk membuat prototype. Disini programmer memulai mengerjakan flow gamenya, dari awal hingga akhir permainan yang akan ditampilkan, seperti antar muka, fitur, dan lain sebagainya. Setelah selesai kemudian di breakdown aset-aset apa saja yang dibutuhkan untuk dikerjakan oleh artist. Disini desainer merancang micro design game yang sedang diproduksi, seperti misalnya fitur kuis dan sistem scoring yang ada didalam game.

Setelah aset sudah selesai di produksi, maka aset-aset tersebut di masukan kedalam game engine untuk mengganti placeholder-placeholder sebelumnya yang telah di buat oleh programmer, lalu tim akan menentukan build version berdasarkan timeline milestone yang telah dibuat, misalkan build version sprint 0.0.1, 0.0.2, dan seterusnya, tergantung dari pencapaian tertentu yang disepakati bersama. Sprint goal disini bisa meliputi pengerjaan game asset, coding, micro design, dan lain sebagainya.

Salah satu tugas producer atau project manager adalah mengatur pace tim pengembangan game. Pace tim disini misalkan kita memiliki waktu empat belas minggu untuk menyelesaikan satu proyek, maka producer atau project manager harus mengalokasikan pekerjaan tim untuk memastikan proyek selesai dalam empat belas minggu, contohnya bekerja secara modular, desainer game mengerjakan micro design dalam jangka waktu tertentu yang juga bersamaan dengan programmer mengerjakan flow game yang ditempuh pada waktu tertentu, sesuai dengan kapabilitas dan fitur yang akan diproduksi.

Dari pemaparan wawancara diatas dapat diidentifikasi metode manajemen produksi game yang digunakan oleh Agate International adalah agile development. Di dalam agile dilakukan metode sprint untuk mengerjakan fitur-fitur yang ada di dalam game, meliputi game asset (concept art, animation, object, dll), coding (base code, mechanics, flow, dll), dan yang berhubungan dengan desain dan mikro desain. Proses manajemen produksi game ini akan menjadi landasan penulis untuk merancang game simulasi.

Setelah melakukan studi lapangan pada komunitas, pengembang game pemula dan pelaku industri, penulis dapat melakukan analisis dengan memetakan permasalahan utama pengembang game pemula pada setiap proses pengembangannya dapat dilihat pada Gambar 8 . 


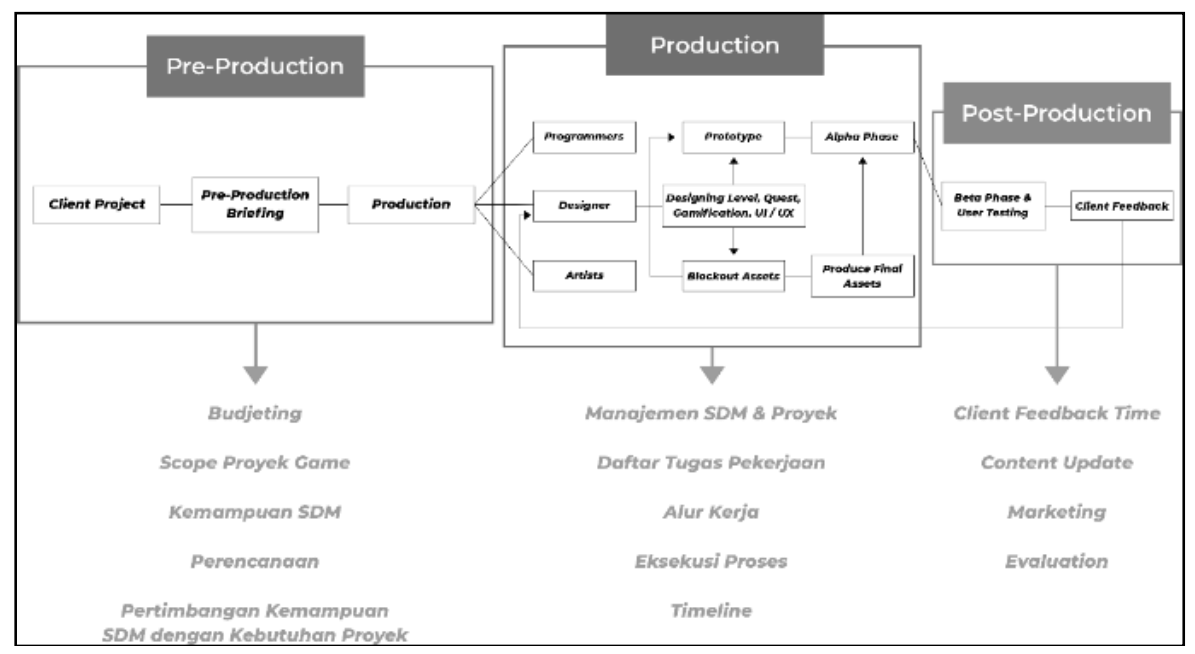

Gambar 8. Permasalahan dalam Metode Manajemen Produksi Game pada Pengembang Game Pemula.

Fase pengembangan game dibagi menjadi tiga, pra-produksi, produksi dan pasca-produksi. Berdasarkan data yang telah didapat, di dalam pra produksi terdapat permasalahan seputar scope proyek game, dimana pengembang game pemula tidak dapat memperkirakan besar kecilnya suatu project dengan kemampuan sumber daya dan keuangan yang dimiliki, sehingga menghambat laju pengembangan pada tahap produksi.

Pada tahap produksi permasalahan yang muncul adalah seputar manajemen sumber daya manusia terhadap tugas-tugas yang harus dikerjakan, dan alur kerja dalam produksi game, serta mengelola / melacak waktu pengerjaan setiap tugas agar pengerjaan tepat waktu (timeline). Pengembang pemula biasanya belum menerapkan struktur atau metode dalam manajemen produksi game, sehingga arus informasi terkait dengan tugas-tugas, alur pekerjaan dan waktu pengerjaan yang dibutuhkan terhadap sesama individu tidak terkomunikasikan dengan baik, sehingga akan menghambat proses produksi game.

Pada tahap pasca produksi, permasalahan yang muncul adalah lamanya waktu yang diberikan oleh klien-klien proyek game sehingga terkadang harus merubah struktur model atau metode dalam proses manajemen produksi game. Hal tersebut menghambat evaluasi yang harus dilakukan, pada akhirnya pembaharuan konten akan terlambat, terkadang tidak maksimal. Adapun Masalah umum pengembang game pemula dalam manajemen produksi game disajikan dalam tabel 1.

Tabel 1. Masalah umum pengembang game pemula dalam manajemen produksi game.

\begin{tabular}{cc}
\hline Fase Pengembangan & Permasalahan Manajemen \\
\hline & Planning \\
Pra - Produksi & Budjeting \\
& Scope Project \\
Employee Skill \\
\hline \multirow{3}{*}{ Produksi } & Timeline \\
& Task Execution \\
& Workflow \\
& To Do / Task List \\
Affective Hub
\end{tabular}


Poin-poin permasalahan pada setiap proses / fasenya akan menjadi landasan mekanisme game yang akan dirancang, dimana pemain akan dilatih menyelesaikan masalah-masalah tersebut melalui metode manajemen agile development.

\section{Ideate}

Dari analisis dan pemetaan permasalahan yang telah dilakukan, penulis memulai merancang game design document untuk menjadi acuan game simulasi yang dirancang. Game simulasi ini dirancang dengan bertujuan untuk memberikan edukasi kepada pengembang game pemula mengenai proses manajemen produksi game. Edukasi ini diberikan kepada pengembang pemula sebagai solusi terkait permasalahan pengembang pemula terhadap aspek manajemen produksi game. Untuk terjalinnya proses edukasi yang efektif, metode yang digunakan dalam perancangan game ini adalah first principle of instruction yang dipopulerkan oleh Merrill (2002). Metode ini berfokus pada instruksi di dalam memainkan game, dengan melibatkan elemen-elemen di dalam game sebagai jembatan informasi kepada pemain. Alur Utama \& Konsep Leveling Game Simulasi Game Dev Management dapat dilihat pada gambar 9.

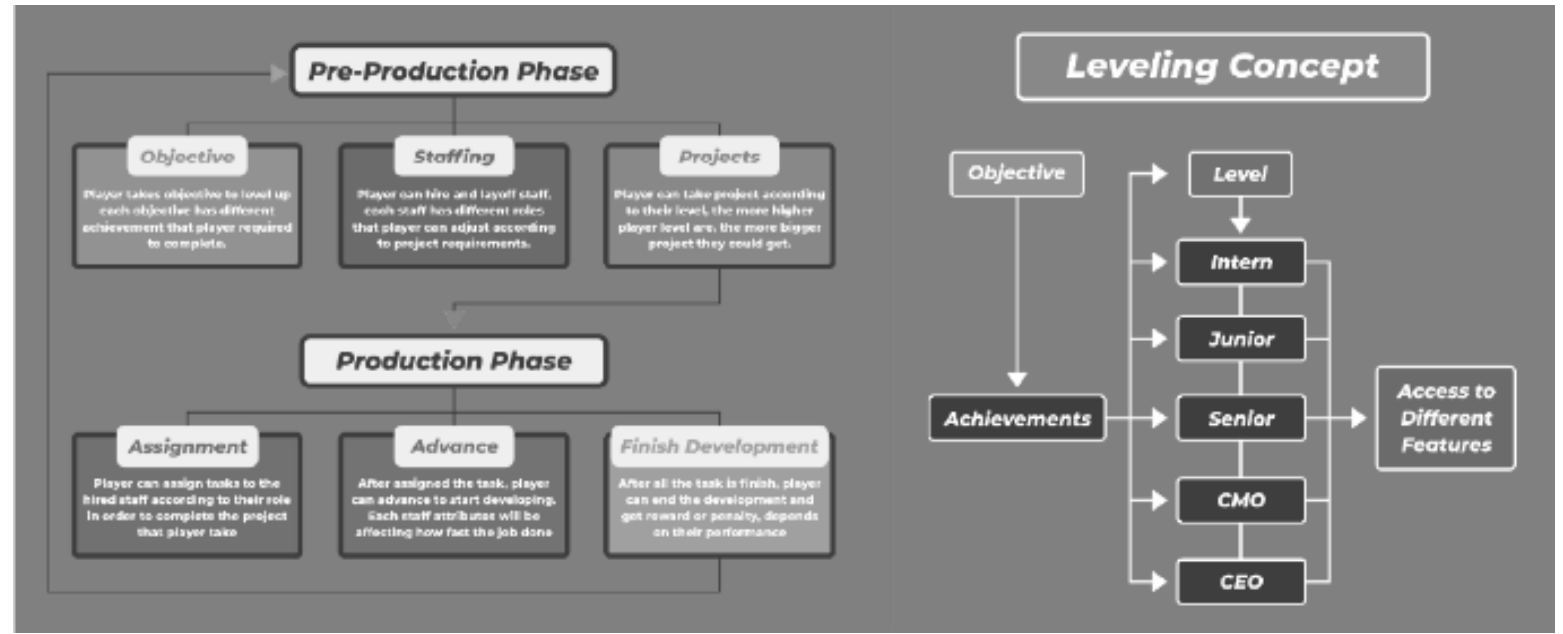

Gambar 9. Utama \& Konsep Leveling Game Simulasi Game Dev Management.

Game yang telah dirancang berjudul Game Dev Management, dalam game ini alur permainan dibagi menjadi dua fase besar, yaitu fase pre-production dan fase production. Di dalam fase preproduction, pemain akan dikenalkan dengan tiga aspek permasalahan manajemen yang umum terjadi di dalam studio game, yaitu scope project, budjeting dan staffing. Pemain dapat memperkirakan ketiga variabel tersebut untuk mencapai tujuan, yaitu proyek yang diambil selesai tepat waktu. Di dalam fase production pemain akan dikenalkan dengan permasalahan to do / task list, yang harus di eksekusi oleh karyawan yang dimiliki, dengan memperkirakan timeline yang tersedia berdasarkan proyek game yang di ambil. Selain itu moral pemain harus mengelola moral karyawan agar tetap baik, agar task execution selesai dengan cepat dan tepat waktu (Gambar 9).

Konsep leveling dalam game ini memiliki progression yang unik (Gambar 9). Jika dalam game secara umum meningkatkan level dengan mendapatkan sebanyak - banyaknya pengalaman, dalam game ini pemain diminta untuk menggapai suatu capaian (achievements) tertentu. Sebagai contoh, untuk naik ke level 2 pemain harus menyelesaikan empat objective awal, yang setiap objective-nya memiliki capaian masing-masing. Untuk memiliki akses mengelola proyek game puzzle, pemain harus menyelesaikan lima proyek game casual dan memiliki sekurangnya tiga karyawan. Lima proyek game 
casual dan tiga karyawan ini merupakan variabel capaian (achievements) yang harus dilakukan pemain untuk memiliki akses mengelola proyek game puzzle.

Setelah memiliki akses dan menyelesaikan objective yang dibutuhkan, pemain akan naik ke level 2 sebagai junior project manager. Proses ini akan berulang hingga pemain mencapai level terakhir yaitu level 5 sebagai $C E O$. Konsep ini mengajarkan kepada pemain terkati dengan strukur organisasi (organization structure), selain pemain dapat memahami peran dalam manajemen produksi game, pemain juga dapat memahai apa saja yang harus dilakukan pada jabatan tertentu di studio game. Konsep struktur ini disebut sebagai Hirarki Penugasan Karyawan yang dapat dilihat pada gambar 10.

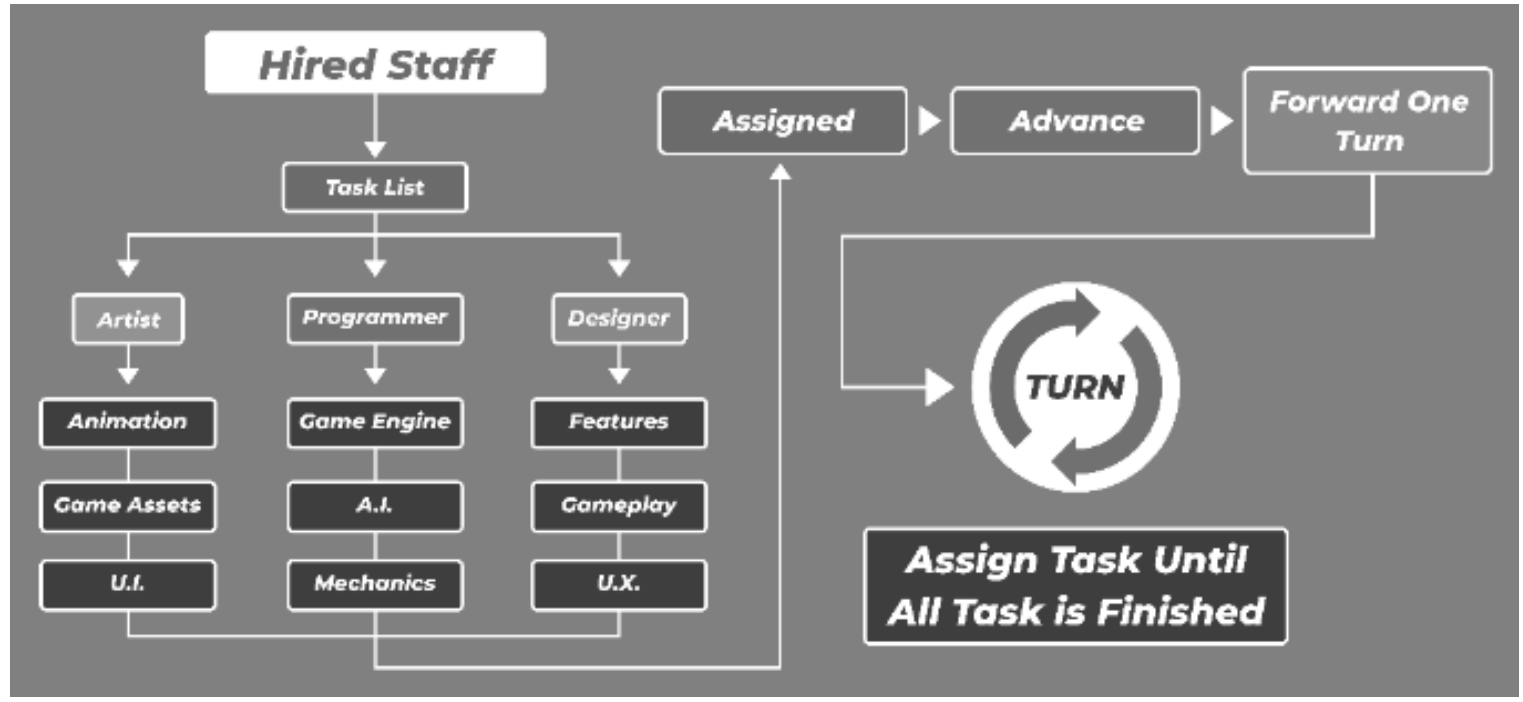

Gambar 10. Hirarki Penugasan Karyawan.

Dalam proses manajemen produksi game, pemain harus menyelesaikan tugas-tugas yang dibutuhkan dalam suatu proyek tertentu, tugas-tugas ini harus diberikan kepada karyawan untuk mereka kerjakan. Jika di dalam suatu tugas terdapat dua tugas atau lebih, maka pemain hanya dapat memilih salah satu saja, yang pilihan-pilihan tersebut akan mempengaruhi dinamika permainan.

\section{Prototyping}

Penulis memulai dengan sketsa awal ruang kerja studio dan merancang seluruh antar muka yang akan digunakan. Aset visual meliputi sumber daya yang dibutuhkan dalam studio game meliputi, pemain, karyawan, meja dan properti lainnya. Antar muka ini dirancang agar mudah untuk dioperasikan oleh pemain dalam mengelola produksi game. Dari sketsa awal penulis mulai merancang visual akhir yang akan digunakan untuk user testing. Penulis menerapkan pendekatan Merrill's First Principles of Instruction untuk mencapai proses edukasi yang efektif. Pada tahap purwa rupa penulis berfokus pada tiga aspek instruksi, diantaranya problems, activation dan demonstration. Penerapan Merrill's First Principles of Instruction di dalam Game Simulasi Game Dev Management dapat dilihat pada tabel 2. 
Tabel 2. Penerapan Merrill's First Principles of Instruction di dalam Game Simulasi Game Dev Management.

\begin{tabular}{|c|c|c|}
\hline $\begin{array}{l}\text { First Principle of } \\
\quad \text { Instruction }\end{array}$ & $\begin{array}{l}\text { Penerapan Elemen Di Dalam } \\
\text { Game }\end{array}$ & Informasi yang diberikan \\
\hline Problem & $\begin{array}{l}\text { Melalui cutscene, story, } \\
\text { gameplay, gameflow dan } \\
\text { objective / quest permainan. }\end{array}$ & $\begin{array}{l}\text { Mengenalkan permasalahan manajemen yang } \\
\text { terjadi pada tahap pra-produksi dan produksi. }\end{array}$ \\
\hline Activation & Melalui in-game tutorial & $\begin{array}{c}\text { Memberikan arahan cara bermain agar } \\
\text { pengenalan problem tersampaikan dengan } \\
\text { baik }\end{array}$ \\
\hline Demonstration & $\begin{array}{l}\text { Melalui quest / objective, project- } \\
\text { project dan skema leveling di } \\
\text { dalam game }\end{array}$ & $\begin{array}{c}\text { Memberikan konten quest baru dan fitur yang } \\
\text { berbeda pada setiap level yang pemain raih, } \\
\text { untuk mendemonstrasikan aspek yang telah } \\
\text { dipelajari }\end{array}$ \\
\hline
\end{tabular}

\section{Problem}

Instruksi problem melibatkan pemain dalam menyelesaikan masalah-masalah yang ada di dunia nyata, dimana dapat menarik pemain untuk mencari solusi terhadap masalah tersebut, dari permasalahan dan solusi yang dicapailah mereka akan belajar. Dalam game yang akan dirancang, permasalahan akan dikenalkan melalui cutscene, story, gameplay, gameflow dan objective / quest permainan. Salah satunya adalah Cutscene yang memberikan gambaran situasi yang terjadi dalam studio game melalui unsur cerita / naratif didalamnya. Selain itu cutscene dapat menarik minat pemain untuk bermain (Gambar 11).



Gambar 11. Cutscene didalam game.

Alur permainan ini terbagi menjadi dua fase, fase pra-produksi dan produksi. Untuk memahami lebih detail dan jelas, penulis memaparkan dalam bentuk bagan yang dapat dilihat pada gambar 12 . 




Gambar 12. Gameplay \& Gameflow keseluruhan didalam game.

Dalam fase pra-produksi pemain dapat melihat menu profile sebagai fasilitas untuk melihat level pemain, capaian (achievement) yang telah dilakukan dan objective yang sedang dijalankan. Informasi yang dipaparkan di menu profile sangat penting agar pemain dapat mengetahui bagaimana untuk melanjutkan progression didalam game (Gambar 13).

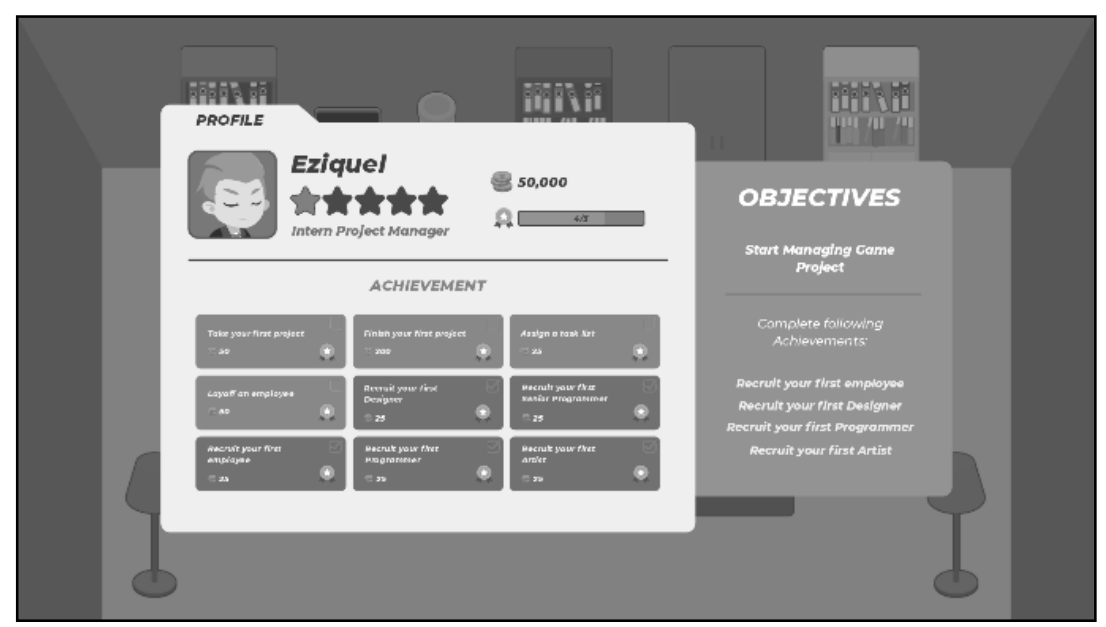

Gambar 13. Menu Profile. 
Dalam fase ini pemain dapat mempekerjakan karyawan mulai dari artist, programer dan game designer untuk mengerjakan suatu proyek. Setiap karyawan memiliki atribut dan tugas masing-masing yang dibutuhkan untuk menyelesaikan proyek game. Makin tinggi level karyawan yang dipekerjakan, makin cepat proyek game selesai, namun untuk mempekerjakan karyawan level tinggi dibutuhkan level pemain yang tinggi, yang dapat digapai dengan menyelesaikan proyek game (Gambar 14).
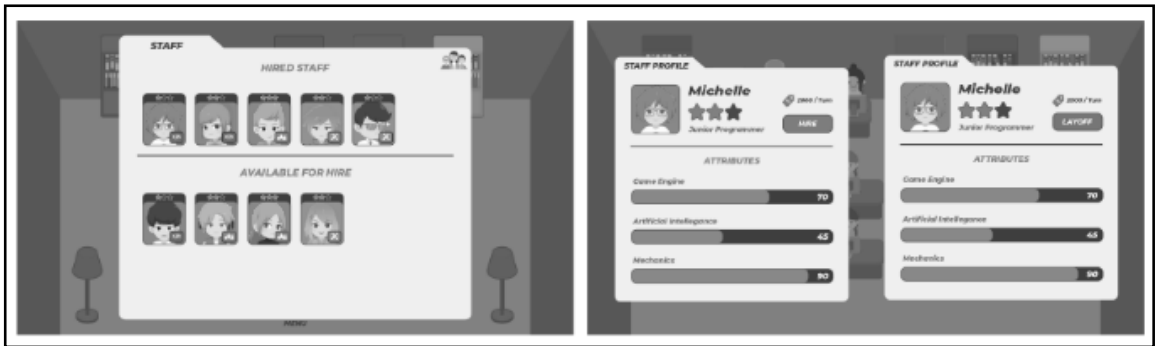

Gambar 14. Menu Perekrutan Karyawan.

Proyek game dapat diambil sesuai level pemain, disini pemain harus memperkirakan proyek game apa yang harus diambil, jika proyek game tidak dapat diselesaikan maka akan menambah resiko kegagalan dan akan mengakibatkan kebankrutan (Gambar 15).

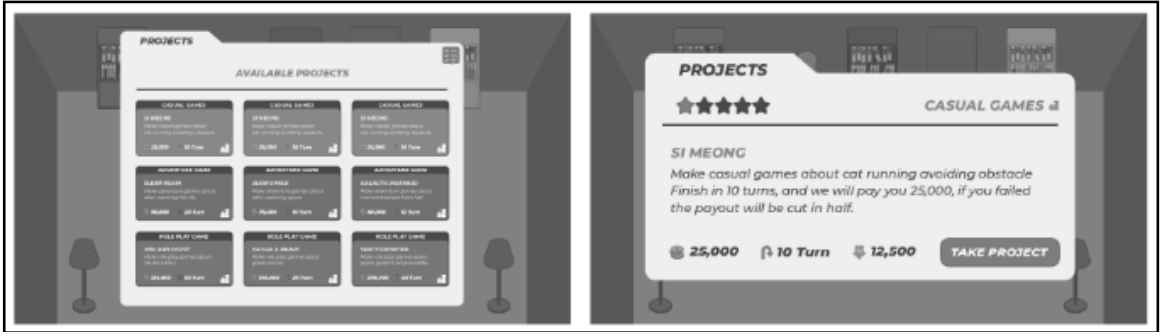

Gambar 15. Menu Pengambilan Proyek.

Dalam fase produksi, karyawan yang telah di pekerjakan dapat diberikan pekerjaan sesuai dengan proyek yang diambil. Setiap karyawan (programmer, artist dan designer) memiliki tugas masingmasing yang harus di beri tugas oleh pemain untuk menyelesaikan proyek game. Setelah memberikan tugas pada masing-masing karyawan, pemain dapat menekan tombol advance untuk menyelesaikan tugas tersebut dan waktu akan berjalan satu minggu, atau didalam game adalah satu turn. Setiap proyek memiliki tenggat waktu yang berbeda, disini pemain diminta untuk mengelola waktu berdasarkan tugas yang diberikan kepada karyawan agar produksi game tidak gagal. Siklus pemberian tugas akan mengulang hingga semua tugas terselesaikan (Gambar 16).



Gambar 16. Fase produksi \& pemberian Tugas kepada karyawan. 


\section{Activation}

Penerapan aspek activation terdapat pada elemen in-game tutorial, dimana game akan memberikan pengenalan dan arahan kepada pemain terkait cara dan langkah-langkah untuk mengelola produksi game. Pengenalan alur dan cara bermain di dalam game akan membantu pemain memahami lebih jauh terkait permasalahan topik yang diangkat di dalam game. Tampilan Penerapan aspek ini dapat diliihat pada gambar 17.



Gambar 17. In-game tutorial proses pengembangan game.

\section{Demonstration}

Penerapan aspek demonstration terdapat pada elemen quest / objective dan quest brief / backlog project-project (Gambar 18), dan skema leveling pemain yang ada di dalam game ini (Gambar 9). Dengan memberikan quest / objective dan proyek yang beragam (Gambar 18), pemain dapat menerapkan hal - hal yang sudah dipelajari sebelumnya, sehingga pemain akan mengingat dan mengetahui bagaimana metode manajemen produksi game berlangsung.



Gambar 18. Beragam proyek yang dapat dimainkan oleh pemain.

\section{Pembahasan}

Temuan dalam penelitian yang dilakukan oleh Matthews, Judy \& Wrigley, Cara (2017:41-54), menyatakan bahwa menggunakan metode design thinking dapat mempercepat pembelajaran menggunakan purwarupa (prototyping) sehingga materi mudah dipelajari. Dalam penelitian yang 
penulis lakukan purwarupa dirancang untuk memberikan pelajaran tentang mengelola proses produksi game menggunakan agile development, agar pengembang pemula mudah dipelajari, Purwarupa yang dirancang melalui proses-proses design thinking yang telah dipaparkan pada bagian sebelumnya.

\section{User Testing}

Pengujian dilakukan kepada dua golongan, yaitu golongan pertama kepada developer Agate International Studio, yang dimaksudkan untuk proses verifikasi / heuristik terhadap konten game yang dirancang. Golongan kedua kepada pengembang pemula dan umum / peminat industri sebagai verifikasi terkait konten edukasi, yang disampaikan melalui media game terhadap pengembang pemula. Data Peserta User Testing dapat dilihat pada tabel 3.

Tabel 3. Peserta User Testing.

\begin{tabular}{ccccccc}
\hline No. & 1 & 2 & 3 & 4 & 5 & 6 \\
\hline Golongan & \multicolumn{2}{c}{ Profesional Ahli } & & \multicolumn{2}{c}{ Pengembang Pemula } & \\
\hline Nama & Aditya & Astri & Liky & Ramzi & Umam & Silfa \\
\hline
\end{tabular}

Dalam user testing, penulis ingin mengetahui bagaimana media game yang telah dirancang dapat memberikan edukasi terhadap target sasaran dalam terkait dengan metode manajemen proses produksi game. Penulis melakukan wawancara terhadap peserta setelah melakukan pengujian. Adapun hasil user testing ini disajikan pada tabel 4.

Tabel 4. Hasil User Testing.

\begin{tabular}{|c|c|c|}
\hline No. & Nama & Aspek manajemen yang diingat dan diterapkan didalam game. \\
\hline 1. & Aditya & $\begin{array}{l}\text { a. Mempertimbangkan aspek karyawan, keuangan } \\
\text { terhadap proyek game. } \\
\text { b. Alur tahapan pra-produksi dan produksi. } \\
\text { c. Pengelolaan waktu dalam produksi game. } \\
\text { d. Pengelolaan uang. } \\
\text { e. Penugasan dalam produksi game. }\end{array}$ \\
\hline 2. & Astri & $\begin{array}{l}\text { a. Tugas-tugas karyawan dalam produksi game. } \\
\text { b. Pengelolaan waktu dalam produksi game. } \\
\text { c. Mengelola keuangan dalam mempekerjakan karyawan. }\end{array}$ \\
\hline 3. & Liky & $\begin{array}{l}\text { a. Tugas-tugas karyawan dalam produksi game. } \\
\text { b. Alur tahapan pra-produksi dan produksi game. } \\
\text { c. Mempertimbangkan aspek karyawan, keuangan terhadap proyek game. } \\
\text { d. Mengelola waktu produksi game. }\end{array}$ \\
\hline 4. & Ramzi & Mengetahui langkah-langkah pengembangan game dari pra-produksi hingga produksi. \\
\hline 5. & Umam & $\begin{array}{l}\text { a. Tugas-tugas karyawan dalam produksi game. } \\
\text { b. Alur tahapan pra-produksi dan produksi game. } \\
\text { c. Mengelola waktu waktu produksi game. }\end{array}$ \\
\hline 6. & Silfa & $\begin{array}{l}\text { a. Tugas-tugas karyawan dalam produksi game } \\
\text { b. Alur tahapan pra-produksi dan produksi game. } \\
\text { c. Mengelola waktu produksi game. } \\
\text { d. Mengelola keuangan dalam mepekerjakan karyawan. }\end{array}$ \\
\hline
\end{tabular}


Dari hasil uji coba kepada dua kelompok, kelompok pengembang pemula dan professional menunjukan bahwa semua peserta dapat memahami materi aspek manajemen dalam proses produksi game yang disampaikan. Hal ini membuktikan penelitian sebelumnya dimana metode design thinking dapat mempercepat pembelajaran menggunakan purwarupa sehingga materi yang disampaikan mudah dipelajari.

Penulis menggunakan metode design thinking karena pendekatannya yang human centered atau berfokus langsung pada penggunanya, mulai dari tahap empathize untuk mengumpulkan data-data permasalahan yang dialami oleh khalayak sasar. Setelah itu penulis melakukan proses ideate, dimana penulis, khalayak sasar dan pengembang game berpengalaman bersama-sama mengidentifikasi dan mengunci permasalahan yang didapat sebelumnya, dimana permasalahan yang ditemukan seputar proses produksi game.

Kemudian penulis melakukan proses ideate, dimana penulis, khalayak sasar dan pengembang game profesional bersama-sama menghasilkan ide dan gagasan-gagasan yang dapat memecahkan permasalahan. Aspek permasalahan utama yang dialami didalam proses produksi game adalah metode produksi game-nya, sehingga digunakan metode agile development sebagai materi yang akan disampaikan kepada khalayak sasar pada purwarupa game yang akan dirancang. Media game digunakan karena penyampaian materi lebih tepat, dimana mayoritas pengembang game khususnya pemula, lebih menggemari media game ketimbang media lainnya.

Dalam tahap prototyping, penulis menerapkan materi tentang agile development sebagai metode manajemen produksi game kedalam game yang akan dirancang. Selain itu penulis menerapkan pendekatan prinsip first principles of instruction oleh Merrill (2002) agar unsur-unsur didalam game terdapat prinsip instruksional yang memudahkan pemain untuk belajar dari materi yang disampaikan.

Hasil uji coba menunjukan keselarasan antara khalayak sasar dan pengembang game professional, dimana purwarupa yang dihasilkan dapat mengajarkan metode agile development sebagai proses manajemen produksi game dengan baik. Dengan menggunakan metode design thinking yang human centered dan penerapan prinsip instruksional dari Merrill (2002), sehingga menghasilkan solusi yang tepat terkait permasalahan proses manajemen produksi game bagi pengembang pemula.

\section{KESIMPULAN}

Hasil pengujian menunjukan bahwa pengenalan permasalahan (problem) terkait pra-produksi dan produksi tersampaikan dengan efektif. Hal ini terjadi karena beberapa aspek, aspek pertama adalah pengimplementasian permasalahan manajemen produksi game seperti pengelolaan waktu, tugas dan alur kerja di studio game, kedalam elemen-elemen game seperti cut-scene dan gameplay (mekanisme dan dinamika permainan).

Aspek kedua adalah penerapan in-game tutorial (activation) yang memberikan arahan kepada pemain terkait mekanisme dan dinamika permainan, sehingga alur informasi di dalam game dapat dimengerti. Aspek yang terakhir adalah penerapan project game (quest) dan objective yang beragam di dalam game simulasi ini, sehingga pemain akan menerapkan pengetahuan yang telah di dapat kedalam kasus yang baru (demonstration).

Ketiga aspek tersebut akan memberi pemahaman lebih dalam terkait proses manajemen produksi game. Maka dari itu bisa ditarik kesimpulan bahwa game simulasi yang mengandung konten proses manajemen produksi game dengan menerapkan metode edukasi first principle of instructions dari Merrill (2002) bisa memberikan edukasi terhadap pengembang pemula secara efektif.

\section{DAFTAR PUSTAKA}

Adams, E., \& Dormans, J. (2012). Game mechanics: advanced game design. New Riders. Adrianto. (2016): Perancangan Game Keselamatan Kerja Safety First Di Kilang Minyak. Tesis Program Studi Magister Desain, Institut Teknologi Bandung.

Bates, B. (2004). Game Design Boston: Thompson Course Technology.

Bethke, E. (2003). Game development and production. Wordware Publishing, Inc. 
Brathwaite, B., \& Schreiber, I. (2009). Challenges for game designers. Boston, Massachusetts: Course Technology/Cengage Learning.

Enah, C., Piper, K., \& Moneyham, L. (2015). Qualitative evaluation of the relevance and acceptability of a web-based HIV prevention game for rural adolescents. Journal of pediatric nursing, 30(2), 321-328..

Fabricatore, C. (2007). Gameplay and game mechanics: a key to quality in videogames.

http://www.cs.north-western.edu/ hunicke/MDA.pdf diakses pada 27 Mei 2010, 13:25

Kapur, S. (2015). Adolescence: the stage of transition. Horizons of holistic education, 2, 233-250. .

Matthews, Judy \& Wrigley, Cara. (2017). Design and Design Thinking in Business and Management Higher Education. Journal of Learning Design. 10. 41. 10.5204/jld.v9i3.294.

Merrill, M. D. (2002). First principles of instruction. Educational technology research and development, 50(3), 43-59.

Miller, C. T. (Ed.). (2008). Games: Purpose and potential in education. Springer Science \& Business Media.

Novak, Jeanny. (2012). Game Development Essentials An Introduction 3rd Edition. New York: Delinar Cengage Learning.

Plattner, Hasso. (2010). An Introduction to Design Thinking Process Guide. Stanford: Institute of Design of Stanford

Sayogo, S. (2019): Perancangan Crew Management Simulation Video Game Sebagai Media Pembelajaran Manajemen. Tesis Program Studi Magister Desain, Institut Teknologi Bandung.

Schell, J. (2008). The art of game design. Burlington (MA).

Tjandra, A. M. (2015). Perancangan Simulasi Digital Pengenalan Mitigasi Erupsi Untuk Anak-Anak Menggunakan Head-Mounted Display (HMD). Fakultas Seni dan Desain. Institut Teknologi Bandung. Indonesia. 